\title{
Growth of Higher Education and its Determining Factors in Cambodia
}

\author{
Mr. Doung Vuth \\ Doctoral Research Scholar \\ Build Bright University, Cambodia \\ Dr. Tapas R. Dash \\ Professor and Senior Vice President \\ Academic \& Student Affairs \\ Build Bright University \\ Phnom Penh, Cambodia
}

\begin{abstract}
The study analyzes the growth of higher education in Cambodia by considering indicators like number of institutions, number of enrolment, number of teachers and expenditure on education. Further, it examines the factors determining the growth of higher education (enrolment) in the country. The results of the study show phenomenal growth of higher education in the country over the period of study. The opening of new universities, institutes and branches of institutes in the country was due to the increasing demand for higher education by a growing knowledge-seekers, the commitment of the government to provide greater access to higher education and incoming of private players into the education sector. It is also revealed from the study that number of students passed out from high schools and per capita GDP at current prices had significant positive impact on the enrolment of students at higher education level in the country. Thus, the findings have implications for education service providers, planners, policy makers, non-government organizations, donors and other stakeholders in ensuring provision of educational facilities to meet the growing demand for higher education in Cambodia.
\end{abstract}

Keywords: growth; higher education; enrolment; determining factors.

\section{INTRODUCTION}

Education has universally been regarded as an important contributing factor in the creation of human capital. In the present competitive economy, higher education plays a vital role as it contributes to the socio-economic development by endowing individuals with the means to improving their knowledge, skills and capability for productive work. As the world is experiencing an unprecedented change, higher education sector has witnessed a paradigm shift from 'state controlled' to an 'open market economy'. Thus, with the establishment of a knowledge-based economy, the demand for higher education keeps growing worldwide and especially, in developing countries. However, the phenomenal growth of higher education poses a number of challenges for the provision of cost-effective and quality higher education to the knowledge-seekers.

Various indicators are considered to analyze the growth of education over a period of time. Among others, the common indicators taken are number of institutions, student enrolments, number of teachers, teacher-pupil ratio, and expenditure on education. In a recent study, Agarwal (2006) shows an impressive growth of higher education in India since its 
independence by considering the number of institutions and enrolments. In a similar note, Suresha \& Mylarappa (2012) by taking into account the type-wise number of institutions, number of student enrolment, public expenditures on higher education and number of pass out students reveal that the growth of higher education in India has been very impressive since the independence of the country. In \& Dash (2011) assess the growth of higher education in general and province-wise disparities in the growth of higher education in particular in the Kingdom of Cambodia over the period 1999-2000 to 2008-09. Their study reveals that higher education in Cambodia during the study period has witnessed phenomenal expansion. This has brought spectacular changes in terms of size, enrolment and number of teachers, etc. However, wide variations are observed in several indicators of educational development among the provinces in the country. In addition, the authors examine the relationship between the gross enrolment ratio (GER) in higher education and the per capita gross domestic product in Cambodia.

A long period of French colonial rule (1863 to 1953) had not resulted in a vibrant education system in Cambodia. The French were reluctant to enhance education for the idea that education would empower Cambodians and tentatively bar France's grip (Clayton, 1995). Sihanouk reversed this colonial obstruction by investing 20 percent of the national budget into education (Chandler, 1993). In 1960s, education sector had experienced a significant growth in the country. Prior to 1970, Cambodia had witnessed nine universities, including the Buddhist University. While six of them were located in the capital city, the rest three were situated in provinces (Mak, 2005). But tragically, the development of Cambodian education had declined since 1970 when the civil war started in the country. Cambodia was eventually plunged into a complete destruction during the regime of Democratic Kampuchea (Khmer Rouge) under the leadership of Pol Pot which came into power in April 1975. The three provincial universities were closed before 1975 - the year of the Khmer Rouge's victory. One of them, the Royal University of Takeo-Kampot was completely destroyed at the start of the civil war (Tan, 1974). All schools and universities were closed during the Khmer Rouge regime (1975-1979). The Vietnamese occupation of Cambodia in 1979 saw an immediate restoration of the education system except higher education (Duggan, 1997).

As Cambodia has had a turbulent past, with many dramatic transitions, several of these have had serious implications for education. However, education activities were revived during the 1980s and have taken a new direction since the early 1990s. It has been realized that over the last few years higher education system has received meaningful support. In the event of public and private cooperation policy as development partnership, the Royal Government of Cambodia has encouraged the private sector to invest in higher education. As a result, a number of private higher education institutions have grown rapidly since 2000 . The privatization measure was a major factor in the rapid expansion of the sector, and at present, private higher education institutions account for a large share of enrolment in higher education (Touch et al., 2014). Thus, over the last decade, higher education in Cambodia has witnessed phenomenal expansion due to increasing attention by both the government and the private sector. Chet (2009) points out that the progress made within the education has given Cambodia both pride and concern at the same time, and it looks as if higher education subsector in Cambodia in enjoying progress, but in fact, it is having a silent revolution that needs more care.

The presence of 110 higher education institutions (HEIs) in Cambodia, presently are supervised by 14 different Ministries in the country. Due to a continuous increase in the demand for quality education by the growing labor force, the focus today is looking at the 
qualitative perspective rather than quantitative perspective of higher education. By international comparison, most of the higher education institutions in Cambodia are very small, with narrow academic and resource base, highlighting issues of efficiency, quality, and coherent system development (Mak, 2005). However, the Royal Government's commitment to enhance the quality of education in the country has led to introduce the Higher Education Quality and Capacity Improvement Project (HEQCIP) in 2010 with the financial support from the World Bank. Thus, in the light of Cambodia's historical background and wider regional integration, it is important to look into the growth of higher education in the country along with its determining factors.

The paper is structured as follows: in section two and three the objectives and methodology of the study are respectively presented. In section four, the growth of higher education over the study period is analyzed. In addition, it examines the factors determining the growth of higher education in Cambodia. Finally, in the last section, the conclusion of the study is presented.

\section{OBJECTIVES}

The main objectives of the study are as follows:

i. To analyze the growth of higher education in Cambodia over the period of 2005-06 to 2013-14; and

ii. to examine the factors determining the growth of higher education in the country;

\section{METHODOLOGY}

To analyze the growth of higher education in the country over the study period, on the basis of consistency and availability of data, several indicators such as number of higher education institutions, number of enrolment, number of teachers and expenditure on education have been taken into consideration. The secondary data used in the study have been collected from the Ministry of Education, Youth and Sport of the Royal Government of Cambodia.

The growth of higher education in the country over the study period has been analyzed by calculating the average annual compound growth rate. In addition, to examine the factors determining the growth of higher education (in terms of enrolment), multiple regression analysis has been carried out with the following equation:

$\log \mathrm{Y}=\alpha+\beta 1 \log \mathrm{X} 1+\beta 2 \log \mathrm{X} 2+\beta 3 \log \mathrm{X} 3+\beta 4 \log \mathrm{X} 4+\mathrm{U}$

Where,

$\mathrm{Y}=$ Enrolment at higher education level;

$\mathrm{X} 1$ = Number of students passed out from high schools;

X2 = Per capita GDP at current prices;

$\mathrm{X} 3$ = Number of HEIs per one million population;

$\mathrm{X} 4=$ Number of HEIs per 20,000 sq. kms. of area; and

$\alpha=$ Intercept term.

$\beta 1, \beta 2, \beta 3$ and $\beta 4$ are the coefficients of $\log \mathrm{X} 1, \log \mathrm{X} 2, \log \mathrm{X} 3$ and $\log \mathrm{X} 4$ respectively.

$\mathrm{U}=$ Error term.

\section{Growth of Higher Education Institutions}

\section{RESULTS OF THE STUDY}

The HEIs (both public and private) in Cambodia had experienced a significant increase over the study period. In 2005-06, the number of HEIs was 63 which had increased to 110 in 2013-14, indicating thereby an increase of 74.6 percent. While in the year 2007-08, the percentage 
change of HEIs was found to be the highest (16.67) as compared to 2006-07, it was the lowest (3.19) in 2010-11 compared to the previous year. The average annual compound growth rate of HEIs was estimated at 7.36 over the period of study. Similarly, the number of universities had grown from 34 in 2005-06 to 46 in 2013-14, indicating thereby an increase of 35.29 percent over the period. In 2010-11 and 2011-12, there were no changes in the number of universities as compared to their previous respective years. Further, in the year 2013-14, the percentage change of universities was negative (-2.22) as compared to 2012-13. Overall, the universities had grown at an average annual compound rate of 3.34 percent over the study period. The study also reveals a significant rise in the number of institutes as observed over 2005-06 to 2013-14. While the number of institutes in 2005-06 was 29, it had increased to 64 in 2013-14, showing thereby an increase of 120.69 percent over the period. In 2006-07, there was no change in the number of institutes compared to 2005-06, and the percentage change in the institutes was the lowest (1.69) in 2012-13 compared to the previous year. Contrary to that, in 2007-08, the percentage change of institutes was the highest (31.03) as compared to 2006-07. Overall, the institutes had grown at an average annual compound rate of 11.23. So far the number of branches is concerned; there was no change in the number from 2009-10 to 2013-14 (five years) and in 2006-07 compared to 2005-06. The branches of institutes had grown at an average annual compound growth rate of 2.00 percent. Both Table 1 and Figure 1 show the growth of HEIs in Cambodia over the study period.

Table 1: Growth of Higher Education Institutions (Public and Private) in Cambodia (2005-06 to 2013-14)

\begin{tabular}{|l|l|l|l|l|l|}
\hline $\begin{array}{l}\text { S1. } \\
\text { No. }\end{array}$ & Year & $\begin{array}{l}\text { Total } \\
\text { Number of } \\
\text { Universities }\end{array}$ & $\begin{array}{l}\text { Total } \\
\text { Number of } \\
\text { Institutes }\end{array}$ & $\begin{array}{l}\text { Total } \\
\text { Number of } \\
\text { Branches of } \\
\text { Institutes }\end{array}$ & Total HEIs \\
\hline 1 & $2005-06$ & 34 & 29 & 32 & 63 \\
\hline 2 & $2006-07$ & $37(8.82)$ & $29(0.00)$ & $32(0.00)$ & $66(4.76)$ \\
\hline 3 & $2007-08$ & $39(5.41)$ & $38(31.03)$ & $34(6.25)$ & $77(16.67)$ \\
\hline 4 & $2008-09$ & $41(5.13)$ & $47(23.68)$ & $37(8.82)$ & $88(14.29)$ \\
\hline 5 & $2009-10$ & $42(2.44)$ & $52(10.64)$ & $37(0.00)$ & $94(6.82)$ \\
\hline 6 & $2010-11$ & $42(0.00)$ & $55(5.77)$ & $37(0.00)$ & $97(3.19)$ \\
\hline 7 & $2011-12$ & $42(0.00)$ & $59(7.27)$ & $37(0.00)$ & $101(4.12)$ \\
\hline 8 & $2012-13$ & $45(7.14)$ & $60(1.69)$ & $37(0.00)$ & $105(3.96)$ \\
\hline 9 & $2013-14$ & $46(-2.22)$ & $64(6.25)$ & $37(0.00)$ & $110(4.76)$ \\
\hline $\begin{array}{l}\text { Average Annual Compound } \\
\text { Growth Rate (\%) }\end{array}$ & 3.34 & 11.23 & 2.00 & 7.36 \\
\hline
\end{tabular}

Note: i. Figures in the parentheses represent change in percentage compared to previous year.

Source: $\quad$ i. Ministry of Education, Youth and Sport, Royal Government of Cambodia. ii. Own computation. 
Figure 1: Number of HEIs (Public and Private) along with change in percentage in Cambodia (2005-06 to 2013-14)

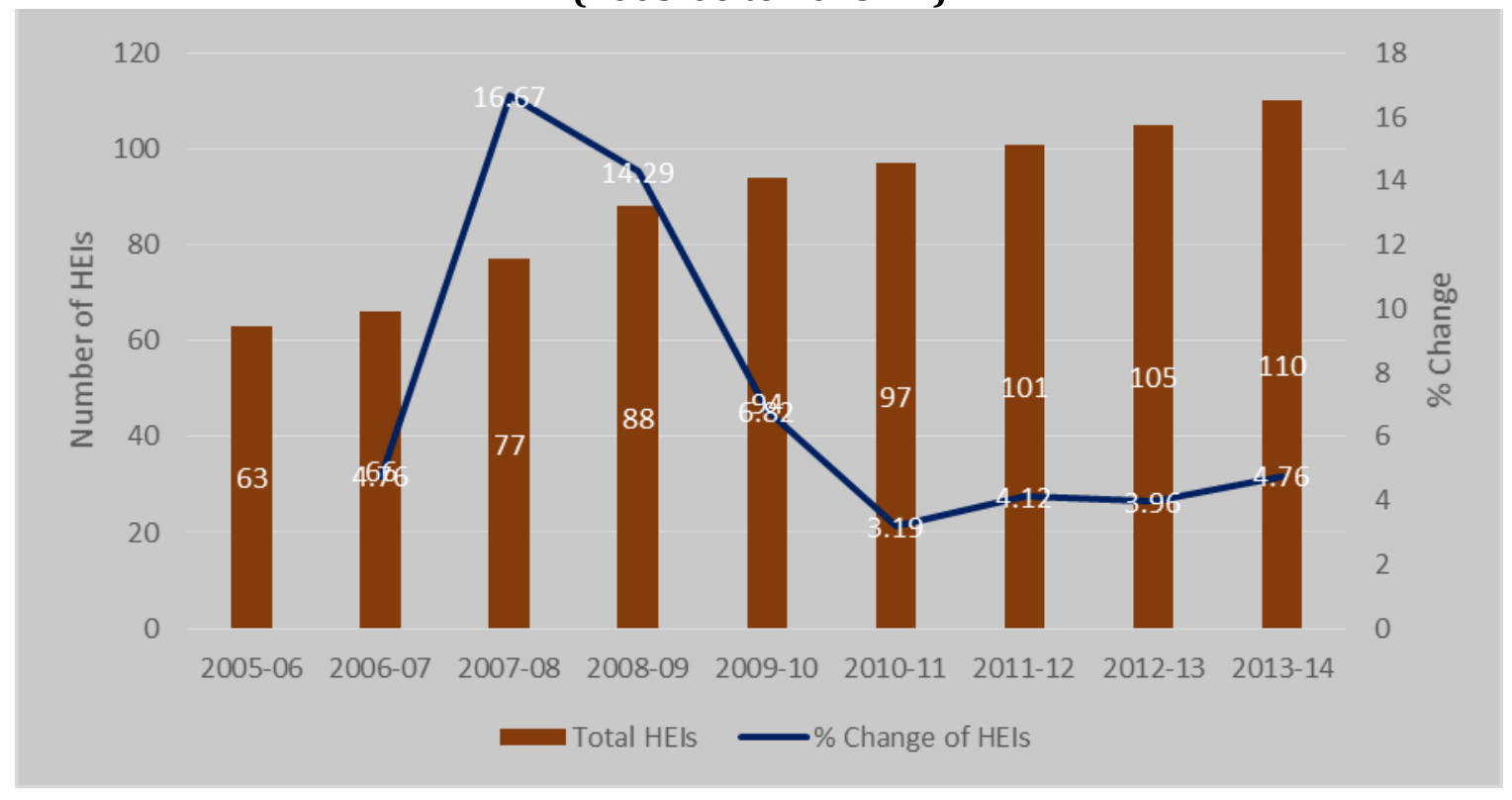

\section{Growth of Enrolment in Higher Education}

The enrolment figure of the country clearly shows an increase of the demand for higher education in the study period except 2013-14 compared to 2012-13. In the year 2009-10, the total enrolment was 195,402 which had increased to 257,470 in $2012-13$, indicating thereby an increase of 31.76 percent over the period. However, as revealed in 2013-14, there was a fall in the enrolment to 249,092 from 257,470 in 2012-13, and hence, the percentage change in the enrolment was - 3.25. This fall in the enrolment in 2013-14 was due to the fall in both Bachelor and Associate degree enrolments which were associated with the increase in the number of unsuccessful students at grade 12. In 2013-14, there were quite a large number of students who did not qualify in the grade 12 examination, and thereby declined to take up further higher education. Overall, the average annual compound growth rate of enrolment was estimated to be 6.48 percent.

In the Associate degree, the enrolment which had grown from 20,020 in 2009-10 to 23,678 in 2012-13, had fallen to 15,635 in 2013-14. Thus, comparing the enrolment of 2009-10 with the enrolment of 2013-14, the percentage change was found to be - 21.9. The enrolment in Associate degree had experienced a negative average annual compound growth rate to -4.13 . Like the Associate degree, in Bachelor degree, the enrolment which had grown from 161,516 in 2009-10 to 216,053 in 2012-13 (33.77 percent change), had fallen to 214,266 in 2013-14. Hence, the percentage change of enrolment was - 0.83 considering the period 2013-14 to 201213. Overall, the average annual compound growth rate was 7.42 over the period. The enrolment in Master program had shown a continuous increase from 2009-10 to 2013-14. While it was 12,885 in $2009-10$, it had gone up to 18,010 in $2013-14$, indicating thereby an increase of 39.77 percent over the period. In the year 2012-13, the percent increase in enrolment was the highest (11.65) as compared to the previous year. Overall, the enrolment in Master program had grown at an average annual compound rate of 8.59 percent over the study period. So far the enrolment in Doctoral program was concerned, a continuous increase over the period 2009-10 to 2013-14 was observed. While it was 981 in 2009-10, it had reached 1,181 in $2013-14$, showing thereby an increase of 20.39 percent. It was revealed from the data that the enrolment in Doctoral program had grown at an average annual compound rate of 
4.55 over the period 2009-10 to 2013-14. Both Table 2 and Figure 2 show the growth of enrolment in higher education in Cambodia over the study period.

Table 2: Growth of Enrolment in Higher Education in Cambodia (2009-10 to 2013-14)

\begin{tabular}{|c|c|c|c|c|c|c|}
\hline $\begin{array}{l}\text { Sl. } \\
\text { No. }\end{array}$ & Year & $\begin{array}{l}\text { Associate } \\
\text { Degree }\end{array}$ & $\begin{array}{l}\text { Bachelor } \\
\text { Degree }\end{array}$ & $\begin{array}{l}\text { Master } \\
\text { Degree }\end{array}$ & $\begin{array}{l}\text { Doctoral } \\
\text { Degree }\end{array}$ & Total \\
\hline 1 & 2009-10 & 20,020 & 161,516 & 12,885 & 981 & 195,402 \\
\hline 2 & $2010-11$ & $\begin{array}{l}22,024 \\
(10.01)\end{array}$ & $\begin{array}{l}185,918 \\
(15.11)\end{array}$ & $\begin{array}{l}14,274 \\
(10.78)\end{array}$ & $\begin{array}{l}1,006 \\
(2.55)\end{array}$ & $\begin{array}{l}223,222 \\
(14.24)\end{array}$ \\
\hline 3 & $2011-12$ & $\begin{array}{l}23,123 \\
(4.99)\end{array}$ & $\begin{array}{l}207,666 \\
(11.70)\end{array}$ & $\begin{array}{l}14,918 \\
(4.51)\end{array}$ & $\begin{array}{l}1,063 \\
(5.67)\end{array}$ & $\begin{array}{l}246,770 \\
(10.55)\end{array}$ \\
\hline 4 & $2012-13$ & $\begin{array}{l}23,678 \\
(2.40)\end{array}$ & $\begin{array}{l}216,053 \\
(4.04)\end{array}$ & $\begin{array}{l}16,656 \\
(11.65)\end{array}$ & $\begin{array}{l}1,083 \\
(1.88)\end{array}$ & $\begin{array}{l}257,470 \\
(4.34)\end{array}$ \\
\hline 5 & 2013-14 & $\begin{array}{l}15,635 \\
(-34.78) \\
\end{array}$ & $\begin{array}{c}214,266 \\
(-0.83) \\
\end{array}$ & $\begin{array}{l}18,010 \\
(8.13) \\
\end{array}$ & $\begin{array}{l}1,181 \\
(9.05)\end{array}$ & $\begin{array}{l}249,092 \\
(-3.25)\end{array}$ \\
\hline \multicolumn{2}{|c|}{$\begin{array}{ll}\text { Average } & \text { Annual } \\
\text { Compound } & \text { Growth } \\
\text { Rate }(\%) & \end{array}$} & -4.13 & 7.42 & 8.59 & 4.55 & 6.48 \\
\hline
\end{tabular}

Note: i. Figures in the parentheses represent change in percentage compared to previous year.

Source: $\quad$ i. Ministry of Education, Youth and Sport, Royal Government of Cambodia.

ii. Own computation.

Figure 2: Enrolment in Higher Education along with change in percentage in Cambodia (2009-10 to 2013-14)

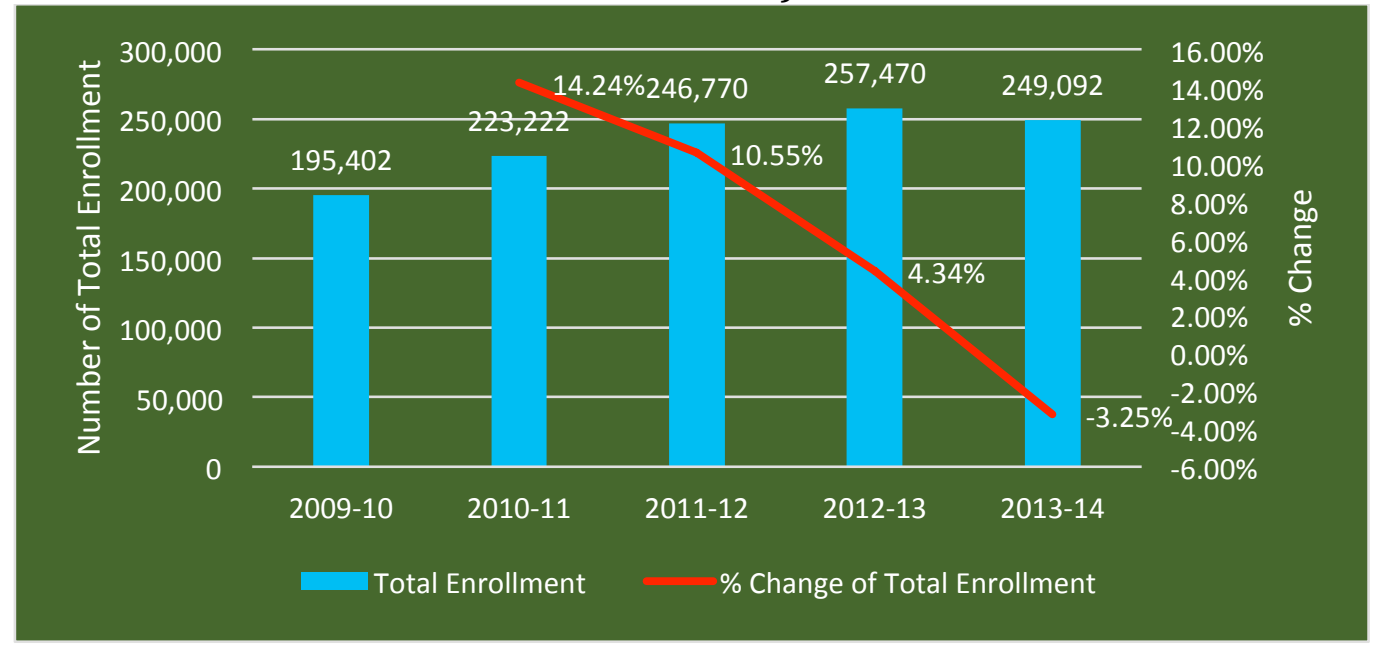

\section{Growth of Teachers in Higher Education}

Corresponding to the increase in number of HEIs and enrolment in various programs, a significant increase in the number of teachers was found over the period 2003-04 to 2012-13. As revealed from the data, except 2006-07, there was a continuous increase in the number of teachers over the study period. While in 2003-04, the number of teachers was 5,378, it had gone up to more than double to reach 11,171 in 2012-13, showing thereby an increase of 107.72 percent over the period. While the highest percentage increase (30.67) was found in 2009-10 as compared to its previous year, it was the lowest percent (0.44) in 2011-12 compared to 2010-11 as shown in Figure 3. Overall, the number of teachers in the country at higher education level had grown at an average annual compound rate of 10.53 percent over the study period. 
Figure 3: Growth of Teachers in Higher Education in Cambodia (2003-04 to 2012-13)

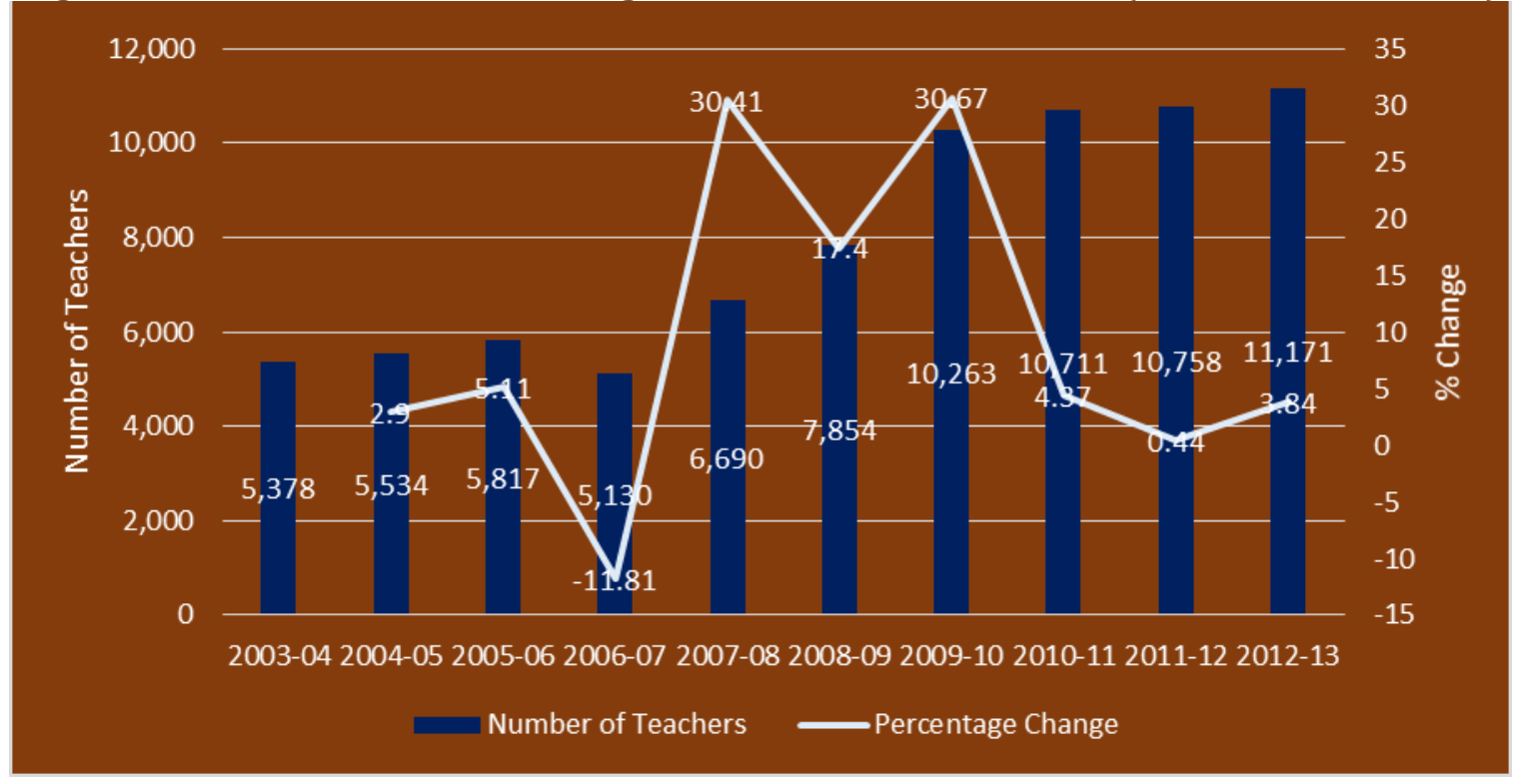

\section{Expenditure on Education}

One of the significant indicators to understand the growth of education in the country is to see the expenditure on education as percentage of GDP and expenditure on education as percentage of total government expenditure. The expenditure on education as a percentage of GDP had gone up to 2.02 in 2013 from 1.67 in 2000. Also compared to 2012, in 2013, there was a considerable rise in the expenditure on education as percentage of GDP. However, contrary to that, expenditure on education as percentage of total government expenditure had fallen from 11.08 in 2000 to 9.91 in 2013. Though there was a fall in percentage, absolutely, the amount spent by government on education had gone up in the country over the study period.

\section{Factors determining Growth of Higher Education in Cambodia}

To examine the factors determining the growth of higher education in Cambodia, multiple regression model has been used. In the model, enrolment at higher education level has been considered as a dependent variable. The four independent variables taken into account were number of students passed out from high schools, per capita GDP at current prices, number of HEIs per one million population, and number of HEIs per 20,000 square kilometers of area. Table 3 shows the regression results.

Table 3: Regression Results

\begin{tabular}{|c|c|c|c|c|c|c|c|}
\hline $\begin{array}{c}\text { Regression } \\
\text { Coefficients/ } \\
\text { Constant }\end{array}$ & $\begin{array}{c}\text { Values of the } \\
\text { regression } \\
\text { coefficients/ } \\
\text { constant }\end{array}$ & $\begin{array}{c}\text { 't' } \\
\text { value }\end{array}$ & $\begin{array}{c}\text { Level of } \\
\text { Significance } \\
\text { (P-Value) }\end{array}$ & $\mathrm{R}^{2}$ & $\overline{\mathrm{R}}^{2}$ & $\mathrm{~F}$ & $\begin{array}{c}\text { Significance } \\
\text { of } \mathrm{F}\end{array}$ \\
\hline$\alpha$ & -34587.97 & - & 0.3852 & 0.9947 & 0.9905 & 235.1080 & $7.0921 \mathrm{E}-06$ \\
$\beta_{1}$ & 0.3619 & 0.9511 & 0.0541 & & & & \\
$\beta_{2}$ & 152.3723 & 2.5066 & 0.0387 & & & & \\
$\beta_{3}$ & -34211.71 & 2.7853 & 0.4093 & & & & \\
$\beta_{4}$ & 28175.14 & - & 0.2617 & & & & \\
\hline
\end{tabular}

Note: $\mathrm{Y}=$ Dependent variable (Enrollment at higher education level)

$=$ Constant 
$\beta 1=\quad$ Regression coefficient of $\log \mathrm{X} 1$, where $\mathrm{X} 1$ is number of students passed out from high schools.

$\beta 2=\quad$ Regression coefficient of $\log \mathrm{X} 2$, where $\mathrm{X} 2$ is per capita GDP at current prices.

$\beta 3=\quad$ Regression coefficient of $\log \mathrm{X} 3$, where $\mathrm{X} 3$ is number of HEIs per one million population.

$\beta 4=\quad$ Regression coefficient of $\log X 4$, where $X 4$ is number of HEIs per 20,000 sq. kilometers of area.

Source: Own Computation.

It is revealed from the regression results that the regression as a whole is significant which is revealed from the ' $F$ ' value $(F=235.1080, P=7.0921 \mathrm{E}-06)$. Among the selected four independent variables, only two variables, i.e., number of students passed out from high schools and per capita GDP at current prices had significant positive impact (significance level 5 per cent) on the enrolment of students at higher education level in the country over the period of study.

\section{CONCLUSION}

The study reveals that there had been a tremendous increase in the number of higher education institutions over the study period in Cambodia. The opening of new universities, institutes and branches of institutes in the country was due to the increasing demand for higher education by students, the commitment of the government to provide greater access to higher education and incoming of private players into the education sector. The growth of enrolment shows an increasing demand for higher education in the country. Further, it is revealed from the study that number of students passed out from high schools and per capita GDP at current prices had significant positive impact on the enrolment of students at higher education level in the country over the period of study. Thus, higher education in Cambodia has made significant progress over the study period. The findings have implications for education service providers, planners, policy makers, non-government organizations, donors and other stakeholders in ensuring provision of educational facilities to meet the growing demand for higher education.

\section{References}

Agarwal, P. (2006). Higher education in India: The need for change. New Delhi: Indian Council for Research on International Economic Relations, working paper no. 180.

Chandler, D. (1993). A history of Cambodia. Colorado: Allen \& Unwin.

Chet, C. (2009). Higher education in Cambodia. In Yasushi Hirosato and Yuto Kitamura (Eds.), The political economy of educational reforms and capacity development in Southeast Asia. Springer Netherlands.

Clayton, T. (1995). Restriction or resistance? Educational development in French colonial Cambodia. Education Policy Analysis Archives, 3 (19), 1-13.

Duggan, S.J. (1997). The role of international organisations in the financing of higher education in Cambodia. Higher Education, 34 (1), 1-22.

In, V. \& Dash, T.R. (2011). Growth of higher education and its relationship with per capita Gross Domestic Product in Cambodia. International Journal of Business and Social Science, 2 (12), 53-61.

Mak, N. (2005). A current update of higher education in Southeast Asian countries: The case of Cambodia. Paper presented at regional seminar on higher education in Southeast Asian countries: A current update. Bangkok: Thailand, September.

Suresha, R. \& Mylarappa, B.C. (2012). Development of Indian higher education in the 21st century. International Journal of Social Science \& Interdisciplinary Research, 1 (10), 70-82.

Tan, K. H. (1974). Role of the universities in development planning: The Khmer Republic case. Singapore. 
Touch, V., Mak, N., \& You, V. (2014). Governance reforms in higher education: A study of institutional autonomy in Cambodia. In N. V. Varghese and Michaela Martin (Eds.), Governance Reforms in Higher Education: A Study of Institutional Autonomy in Asian Countries. Paris: UNESCO, IIEP. 